\title{
Thomas Rescum Sterns at the Battle for Vicksburg
}

\author{
R O B E R T A. McC OW N
}

The American Civil War is one of the subjects for which the University Libraries have strong manuscript holdings. There are well over 50 entries in the manuscript card catalog for Civil War diaries, letters, documents, or larger collections of papers. As might be expected, more than half of these manuscripts are concerned with soldiers in Iowa infantry and cavalry regiments. ${ }^{1}$ Yet there are also handwritten documents relating to Ohio, Pennsylvania, Illinois, New York, Wisconsin, and Michigan military units. ${ }^{2}$

Serious interest in Civil War era manuscripts at The University of Iowa began in the 1950s. In 1951 the Lincoln library of Judge James W. Bollinger came to the University Libraries. Four years later, in March 1955, the quarterly journal Civil War History started publication on the lowa campus under its first editor, Clyde Walton of the University Libraries. This magazine continued to be published on the Iowa campus until 1968. The end of the 1950s saw the beginnings of the Civil War Centennial activities. With this renewed curiosity about the war, significant gatherings of research material were deposited in the Special Collections Department. Since then, new collections of papers and records have come to the libraries, creating a rich resource for the study of the war between the states.

In 1982, Virginia Edwards of Eldridge, Iowa, donated an additional Civil War collection relating to the Sterns family. This set of papers is contained in four document boxes and consists of 365 pieces of corres-

\footnotetext{
${ }^{1}$ There are manuscripts concerning the $1 \mathrm{st}, 2 \mathrm{nd}, 3 \mathrm{rd}, 4 \mathrm{th}$, and 8 th Cavalry Regiments and the $2 \mathrm{nd}, 3 \mathrm{rd}, 7 \mathrm{th}, 11 \mathrm{th}, 12 \mathrm{th}, 15 \mathrm{th}, 17 \mathrm{th}, 19 \mathrm{th}, 24 \mathrm{th}, 25 \mathrm{th}, 26 \mathrm{th}, 27 \mathrm{th}, 29 \mathrm{th}, 30$ th, 37 th, 38th, and 45th Infantry Regiments.

${ }^{2}$ Material on the following regiments can be found: California, 4th Infantry; Illinois, 34th, 95th, 104th, and 129th Infantry; Michigan, 15th and 23rd Infantry; New York, 1st Cavalry and 154th Infantry; Ohio, 31st, 66th, and 114th Infantry; Pennsylvania, 18th Cavalry, 5th and 149th Infantry; and Wisconsin, 3rd and 29th Infantry. In addition, there are manuscripts concerning the U.S. Colored Volunteer Infantry: 12th, 59th, 62nd, $101 \mathrm{st}$, and 125 th.
} 
pondence, newspaper clippings, and other documents plus some tintypes and daguerreotypes that are in a truly wonderful state of preservation. Through the 77 letters that Thomas Rescum Sterns wrote to his wife, a present-day reader can see the Civil War as it was experienced by an observant 23-year-old private during the years 1862 and 1863 .

The story of Thomas Rescum Sterns begins in upstate New York. He was born on January 18, 1839, in Amsterdam, Montgomery County, a town on the Erie Canal 30 miles northwest of Albany. His wife-to-be was also from the Empire State. Lavinia C. Van Deusen, daughter of Henry and Eliza Near Van Deusen, began life in Pine Plains, a village in Dutchess County, 25 miles northeast of Poughkeepsie, on September 13, 1840. Lavinia, her brother Edward, and her parents moved to Wisconsin around 1858.

The young couple was married on April 25, 1860, in Jefferson County, a farming area in southern Wisconsin. The new husband was engaged in farming and teaching school. In 1862 he was issued a teacher's thirdgrade certificate for the common schools of Jefferson County. Then on August 14,1862, he enlisted in the army to serve three years and was paid a bounty of $\$ 25$. Sterns was mustered into the service as a private in Company F, Twenty-ninth Regiment, of the Wisconsin Infantry, on September 27, 1862, at Camp Randall, Wisconsin. This regiment was recruited principally from Jefferson, Dodge, Dane, and Columbia counties, the area around Madison. Military records describe Thomas Rescum Sterns as having a light complexion, blue eyes, dark hair, standing five feet, eight and three quarters inches tall, and weighing about 175 pounds.

From the time he arrived at Camp Randall in Madison, Wisconsin, on Saturday, September 20,1862, until his death, Sterns wrote at least 77 letters to his wife Lavinia. ${ }^{3}$ In his first letter, Sterns wrote about army food, a favorite topic of soldier correspondents.

\section{Camp Randall, Madison, Wis.}

Sept. 24, 1862

\section{Dear wife}

I take the pleasure of writing a few lines to you to let you know how things are here in camp. We arrived here last saturday about 8 o'clock in the evening. After we arrived each one eat his allowance and went to repose. Our bunks as they are called are just wide enough for two to sleep in. In which is put about a handful of straw and then we spread down a blanket and crawl on that and spread another over us and in this we start for the land of dreams.... My duty... last night... was to guard prisoners, that is men from our regiment that got drunk and was shut-up in the guard house. We had three

\footnotetext{
${ }^{3}$ Spelling and punctuation have been modernized occasionally to make for easier reading. I wish to thank my colleague Judith L. Macy for her superb help in transcribing these letters.
} 
last night, but none from our company.... For breakfast we have bread meat and tea or coffee for dinner coffee bread and meat for supper meat bread and coffee. Sometimes we have in addition to the above potatoes or beans.

I suppose you have heard what news there has been. I have not heard much and all I have heard is the President has issued a proclamation declaring all slaves free after the 1 st of Jan., and also for 400,000 more troops. ...

From your Husband, Rescum.

The Twenty-ninth Infantry left Wisconsin on November 2, 1862, and went to Coahoma County, Mississippi, in the northwest part of that state across the Mississippi River from the town of Helena, Arkansas. In his letter of November 12, Sterns wrote in a humorous way about "crackers," a flour and water biscuit known commonly among soldiers as "hardtack."

Camp Salomon, Coahoma Co., Miss.

Wednesday, Nov. 12, 1862

My dear wife

Although it was but sunday that I wrote to you, but I only called that but a part of a letter. I thought I would try to finish it now. I had a dream a few nights ago which seemed just as I wished it could be. It was like this. I thought I was at home with you. I thought too that the war had closed and that George and I came home together. I dreamed that peace was fully restored to our country and the rebels cleaned out completely. This was not all but I have forgotten the rest of it. But if that would come true I would not care for the rest. You need not think by this that I am homesick for I am not at all nor neither am I a coward by any means. But I . . . would rather be at home. But as I have said somebody must endure the hardships of this war. And if I cannot stand it well I shall get discharged, but I have stood better than the most of our company for a good share of them have been sick little or much. . . .

We had some fun a few nights ago. Now I will tell you what it was. Our pickets (maybe you want to know what pickets are? Well they are guards that are stationed about a mile or more or may be less just as the case may be) got scared at a mule which they supposed to be guerillas and fired the alarm and so we had to form a line of battle to defend ourselves and some of the boys were so scared that they did not load their guns until their scare was over. There was one fellow that had two loads in his gun. Maybe you think I was just fool enough to be scared out of my wits but that was not so.

We soldiers had a chance to an election day which we did at Cairo on the banks of the Ohio. There were 70 voters in our Co., only 16 being Dem. which left the Republicans 54 majority. Pretty good for us.

Oh! yes a few words about our fare. As I told you in my other letter our bread is principally crackers. A day or two ago Dolph had been to dinner eating crackers of course. We found one that was marked 1801 and another the date being still earlier. It being made in Nazareth 


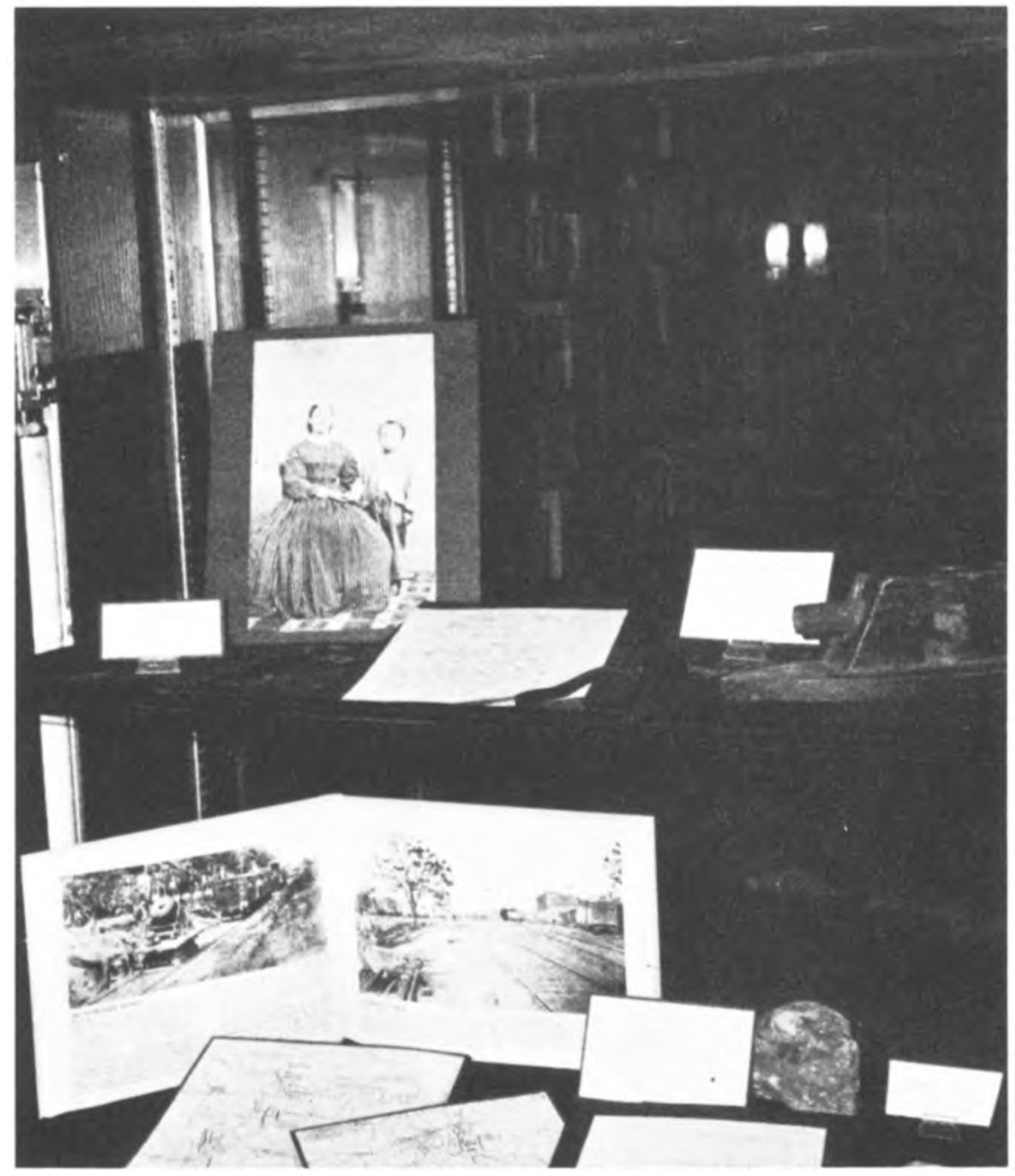

One panel from an exhibition featuring the Civil War letters of Thomas Rescum Sterns, who participated in the Vicksburg campaign in the spring of 1863 . The Sterns letters were given to The University of lowa Libraries in 1982 by Virginia Edwards of Eldridge, lowa. 
B.C. 36. You may judge whether they are old and hard or not. You need not be afraid of my getting killed by the enemy's bullets for this reason. Just before $I$ go into battle, if such may be the case, I shall fill myself as full as possible with these crackers which of course are hard and then I shall oil my belly and of course if the bullets strike me then glance as though they had struck an ironclad gunboat. Who would not be a soldier at $\$ 13$ a month, a plenty of hard crackers to eat and a chance to shoot rebels.... From one that always has and always will love you. Write soon.

\section{Rescum}

On November 15, Sterns was part of a White River expedition into the interior of Arkansas. After this journey, his regiment returned to Camp Salomon. The letter of December 14 tells of "guarding cotton." The Civil War did not lessen the desire to obtain cotton grown in the Southern states and during the conflict there was some trade of the product, Southern farmers and property holders exchanging cotton for money or supplies. Some of these supplies eventually made their way to the Confederate Army. As a consequence, this trade was probably more beneficial to the South than the North. Speculation in cotton was participated in by corrupt officers and men in the volunteer service. Northern soldiers were bribed to overlook contraband going through their lines. ${ }^{4}$

Camp Salomon, Miss

Sunday, Dec. 14, 1862

My Dear wife,

As usual I will try to scratch a few lines to you to keep you from being in suspense as much as possible.... We are lying still and doing nothing except guarding cotton that is bought and sold by the officers for speculation \& to line their pockets with. The only thing that (in my opinion) is the prolongation of this war but soon that will be played in this part for I should think they had got about all the cotton there was to be got within reach of here. Another reason is why our soldiers does not do more fighting is this: our Generals have a particular way of fighting to save life and I believe them in that respect. But stop! Now the question is whose lives are they saving. Is it those of our own soldiers or the rebels? It is my private opinion publicly expressed that they are saving those of the rebels, for if they should keep our northern troops in this southern climate two years there would more die by disease (yes I would say 3 times the number) than they would lose by the bullets if they done it all in hard fighting. The rebels of course are accustomed to this climate and can stand it and so our

\footnotetext{
${ }^{4}$ For cotton speculating see James Ford Rhodes, History of the United States from the Compromise of 1850 to the Final Restoration of Home Rule at the South in 1877 (7 vols.; New York: Macmillan, 1912), V, pp. 274-313. The analysis by Rhodes is based upon a careful examination of The War of the Rebellion: A Compilation of the Official Records of the Union and Confederate Armies. Also, James M. McPherson, Ordeal by Fire: The Civil Warand Reconstruction (New York: Knopf, 1982), pp. 378-83.
} 
soldiers can for the space of a year or 18 months. The second year they will fail fast especially in the hot season.

The Democrats I understand have carried their point almost universally throughout the north \& if they have we may look out for a Compromise soon. We seem to have a great many generals that are afraid of hurting the rebels. Take for instance Gen. McClellan's march pursuing the retreating enemy after the battle of Antietam. He marched all of six miles a day which of course gave the rebels a chance to cross the river and get out of his reach. Now if he had marched 20 miles a day instead of 6 , he could have taken Jackson with his whole force. I might mention a number more similar to the above. I say emphatically that is enough to make any one feel gritty if they do live where there is plenty of sand.

We are having good times here at present living comfortable in our mansion, eating three times a day, etc., etc. At evening we sit around our fire spinning yarns or employ ourselves in reading newspapers when we can get them and sometimes we take to reading story books which we buy here. I have made up my mind that novel reading was the least of bad habits. I have bought two books and intend to send one of them to you at the same time I send this letter I think (for that kind of reading) it is a very good story. . . .

\section{Your affectionate husband Rescum}

At the end of December, Sterns and his regiment crossed over to Helena and then down the Mississippi to Prior's Point, Mississippi, where the men skirmished with some guerrillas. The troops returned to Helena, but they were soon on transports and gunboats again for another trip up the White River, this time to Devall's Bluff, Arkansas.

Prior's Point, Miss.

Friday, Dec. 26, 1862

My dear wife

Since I wrote to you last our Regt. has been a very little on the move. We left camp Salomon on the 23rd for Helena that is directly across the river and we arrived there that evening and such a camping place you nor I never saw. Well it was something like this. It was quite rough and bluffy, a hill and then a ravine, a ridge, then a gully. These hills, well in fact the whole ground, is timbered with white beech, oak, dogwood, cypress, sassafras and others that I did not know the names of.

I said the country was rather rough and so it was and our Co. camped near the top of quite a large hill and I should judge from the foot up to where we lay was about $1 / 4$ of a mile. It was so much of a side hill where we pitched our tent that it [was] almost impossible to keep in our sleeping place. Some of the boys had quite an idea of tying a rope around their neck, then tie the other end to a stake above them \& some thought of trying another way, that is to drive a stake in the ground and lay straddle of it. But how many of them tried these experiments I do not know at least I did not. But I awoke quite a number of times during the night and found myself about my length 
out of the tent. Every move I would make would slide me further down the hill until I would get so far that my pants would work up till my legs would get chilled which would wake me then I would have to crawl back and so I managed to spend the night. The morning came and it put much in mind of a spring morning in Wis. and about nine o'clock (it might have been after), just as we had begun to fix our tents so as to be comfortable, we received marching orders and went to work immediately ... packing up our knapsacks.... and marched down to the river, then from there on the boat and by the time we were all loaded it was some time after dark. Then our mail matter came and brought me a letter from you which of course did not come amiss though it has been some time on the way and seemed something like an old letter dated Dec. 14. We spent that night on board the boat. The next day (Christmas) we arrived at this place (Prior's Point).

It is not a very large place though I should [think] from the looks of things it had been once a business place. We landed here about noon and the first thing I was detailed to help unload the boat and to do work generally and kept me at it till about dark then I went camp and then to my tent and laid down to repose.

Just as we came in sight we saw three men on horse back skedaddling. Some of our men fired after them but it was too long a range for our guns. The artillery that were with us fired two shells after them but I think did no damage. There was a portion of the Regt. selected as pickets. They loaded their pieces and started in advance, that is across the levee, and as they came upon the levee they saw about a dozen guerillas and fired on them but the distance was too great but they killed one horse.

A part of our Co. have rec. new tents which will not admit but four. They are called wedge tents. Hiram, Dolph, William \& myself live in one of that kind now. Well for the first we lay down to repose under our new tent and on our new camping ground to close our Christmas and such a Christmas I never spent before, no sleigh ride, no skating, no snow, nor no nothing. The day was something like April considerable cloudy but not cold nor rainy until night when it rained some but it looks like clearing up now. About two o'clock (or a little after) our Captain came to our tent awoke us out of a sound sleep and told us to strap on our accouterments and be ready at a minute's calling so we dressed ourselves put on our cartridge boxes \& belts and lay down with our guns by our side and hugging them a close as we would our wives. In this way we went to sleep again and did wake again until roll call about six o'clock. We had spoke (a day or two before hand) about having a dinner for Christmas but our Gen. kicked that all over by giving us marching orders and whether we will get anything for New Year or not $I$ do not know yet but $I$ think not anything extra....

From your affectionate husband

The morale of the troops often suffered during winter quarters. If civilians back home seemed unpatriotic, the soldier's spirit dropped. In the North the Copperhead movement was made up of people who sympathized with the South or wanted to compromise with the Rebels. 
Helena, Arkansas

Wednesday, March 18, 1863

Dear wife

I will try again to write a few lines to you to let you [know] how I am getting along at present.... There is one thing going on in the north which makes the soldiers feel rather gritty that is the Copperhead clubs and the rebel sympathizers in the north. We have come here to save our country. Now to have our northern men work against us is rather provoking. If it should come their turn to fight for their country they ought to do it rather than to fight against it for they are no better than we are but if they do not close their mouths soon we will give secesh a wipe and finish up the war and then we will come and serve the copperheads still worse and I think we are able if our Generals would let us go to work. ...

\section{From your loving husband Rescum}

By the spring of 1863 , the North controlled the Mississippi River except for the stretch between Vicksburg, Mississippi, and Port Hudson, Louisiana. As long as the Confederacy held this, the North was denied use of the river. Early in April 1863, Sterns and the regiment once more left Helena, this time for the struggle for Vicksburg. They landed at Milliken's Bend, Louisiana, to the northwest of Vicksburg, and marched down the west bank of the Mississippi through swamps and bayous, all the while building bridges constructed of material found in the vicinity. In a critical amphibious operation, the regiment crossed the Mississippi at Bruinsburg, south of Grand Gulf, and marched towards Port Gibson, a small village about 35 miles south of Vicksburg. Here Sterns participated in his first major fight, the opening battle of the Vicksburg campaign, which he described vividly in a letter to Lavinia.

\section{Camp ten miles north of Port Gibson} Tuesday, May 5, 1863

\section{My dear wife}

When I wrote to you last I was in Louisiana on a march southward and we still continued to march in that direction until April 30 when we crossed the river again into Mississippi. On the 29th we arrived nearly opposite Grand Gulf, a fortified place at the mouth of the Black River and it was bombarded that day by our gunboats. We staid opposite that place till sometime in the afternoon when we resumed our march again as I have stated above and crossed the river at Rodney the 30th in the morning and at four o'clock everything being in readiness we again resumed our march and continued until daylight on the first of May.

I would tell you how many troops there were if I knew but you at the north know better than we do here. Well at daylight May 1st we made a halt to get our breakfast and cannonading immediately commenced between our batteries and those of the rebels that were stationed near a church called Magnolia church and by the time we 
could and in fact some had not got their breakfast we were called on to meet the rebels we were formed in line on the brow of the hill and were marched uphill and down through cane brakes most of the way until we came to an open space when we were ordered to halt and lay down and although I was very sleepy I could not get to sleep on account of shell grape and musket balls whizzed so lively ... Musketry and cannonading had been kept up for an hour or more on both sides when we were again ordered forward and soon we came to an open field when we were again halted and laid down again and as soon as we did so I looked around and saw a rebel cannon planted behind us within the distance of 20 rods which made me look for a chance to get out of the way when I saw some of our soldiers come forward and take the rebels prisoners and also took possession of the cannon which relieved me greatly.

Soon we were again with 11 th $\mathrm{Wis}$. ordered to move to the right but before our boys could get a chance to fire a single volley the rebels where we were either killed or taken prisoner except a few that skedadled. By this time we were somewhat fatigued and our division here came to a rest while some fresher troops went in. After we had rested a while we were this time ordered (with the 24th Indiana) forward this time were marched into murderous shower bullets and for one hour and twenty minutes we stood giving and taking the messengers of death.

I have not time to write any more at present but suffice it to say that no one was hurt that you know except Ed Hawes who was killed. Write to mother for me when you get this.

[No complimentary close]

After the Battle of Port Gibson, the Union Army, under the overall leadership of General Ulysses S. Grant, moved quickly inland by hard marching into the state of Mississippi. On May 16 Sterns was a second time in a ferocious battle at Champion Hill, Mississippi, midway between Vicksburg and Jackson. This was a climactic engagement in a decisive campaign. With another Northern victory, Confederate forces under Lieutenant General John C. Pemberton retreated to the formidable fortifications around Vicksburg, a city built on a 200 -foot bluff. There were unsuccessful Union assaults on the entrenchments on May 19 and May 22 , and then Grant decided to starve the city into submission. ${ }^{5}$

Near Vicksburg, Miss.

Thursday, May 28, 1863

My Dear wife

Once more I will try to pen a few lines to you to let you know that I am still in the land of the living. . . Today is about the tenth day of the siege of this place the fighting has been done mostly by

\footnotetext{
${ }^{5}$ One of the best short accounts of the Battle of Vicksburg is "Struggle for Vicksburg, The Battle \& Siege That Decided the Civil War," Civil War Times Illustrated, Vol. 6, No. 4 (July 1967). This article makes up the entire issue of the magazine and is accompanied by excellent maps.
} 
sharpshooting and cannonading but not very brisk the gunboats \& mortars giving them a few shells occasionally from the river and the batteries on the land throwing some solid shot and some shell and the sharpshooters to keep them down behind their breastworks and thereby to protect our gunners. The "Rebs" send a very few musket balls at our sharpshooters but they are of no avail on account of our rifle pits. We have got Vicksburg completely surrounded and as soon as our friends get tired of hearing our salutation they can come out and surrender or they can give us an invitation to come in on peaceable terms for the place is large enough for us both and we must (and will) occupy it as soon as our friends get tired of our noise but how soon that will be I cannot tell but they must get hungry soon for they can get no more to eat than what they have got and I do not believe they have got much left by this time. . .

\section{From your ever loving husband}

General Pemberton and the Confederate forces surrendered on July 4, 1863. For Grant and the North it was a great victory and it came at the same time as the Union success in turning back General Robert E. Lee at Gettysburg. The Confederacy was cut into two parts and the North controlled the Mississippi. Early in August 1863 Sterns and his regiment left the Vicksburg area for Natchez, Mississippi.

Natchez, Miss.

Wednesday, Aug. 12, 1863

Dearwife

It has been ten days since I wrote to you but it is not my fault for soon after I wrote last we left Vicksburg for this place and before I could get straightened around we were ordered to march back in the country about twenty miles and since then we have been dodging about hardly staying two nights in one place and did not get back until yesterday so you see this morning is the first chance I have had to write at all since I left Vicksburg.

This place is as pretty a place as I have seen in the south and in fact $I$ think it is as nice as any I ever saw. The location is about as near as I can judge 200 feet above the river. The buildings are costly and handsome generally and the whole town is completely shaded with various kinds of trees and the gardens are filled with the richest kind of shrubbery and carefully cultivated. . . .

I am at present again a little under the weather on account of being a little lame. It was caused by my getting wet the day we started to go back into the country and started off as soon as the shower was over without having a chance to dry myself but I am on the gain now and I think in a few days I shall be all right again. . . .

\section{Your ever loving husband}

Rescum

Thomas Rescum Sterns was discharged at Carrollton, Louisiana, on August 24, 1863, because of heart disease. He died on September 2 on board a steamer, was buried at the National Cemetery in Memphis, Tennessee, and was survived by his wife Lavinia and a two-year-old son, Albert Henry. He had had the will, but not the strength, to endure a tragic war. 